Cahiers $d u$ MONDE RUSSE

\section{Cahiers du monde russe}

Russie - Empire russe - Union soviétique et États indépendants

\section{$51 / 2-3 \mid 2010$}

Dynamiques sociales et classifications juridiques dans l'Empire russe

\title{
The shifting place of women in Imperial Russia's social order
}

La place variable des femmes dans l'ordre social de la Russie impériale

\section{Alison K. Smith}

\section{(2) OpenEdition}

\section{Journals}

Electronic version

URL: https://journals.openedition.org/monderusse/9193

DOI: $10.4000 /$ monderusse. 9193

ISSN: $1777-5388$

Publisher

Éditions de l'EHESS

\section{Printed version}

Date of publication: 9 September 2010

Number of pages: $353-367$

ISBN: 978-2-7132-2315-0

ISSN: $1252-6576$

\section{Electronic reference}

Alison K. Smith, "The shifting place of women in Imperial Russia's social order", Cahiers du monde russe [Online], 51/2-3 | 2010, Online since 26 October 2013, connection on 02 September 2022. URL: http://journals.openedition.org/monderusse/9193 ; DOl: https://doi.org/10.4000/monderusse.9193

This text was automatically generated on 2 September 2022.

2011 


\title{
The shifting place of women in Imperial Russia's social order
}

\author{
La place variable des femmes dans l'ordre social de la Russie impériale
}

\author{
Alison K. Smith
}

1 During the eighth revision of the census rolls in 1835, a number of women living in Vil'na found themselves in need of a new soslovie. The revision, which aimed to clean up the tax rolls of town and village societies across the empire, also demanded that unregistered subjects of that empire find themselves an official place in the social hierarchy by adding their names to the lists. Although they were not subject to taxes, women were included in the revision, and thus sought to formalize their places in society by having their names written on these official lists of the population. In Vil'na, several women had undergone a recent change in their status, from official nobles to non-entities. Anna Martinova Sadkevichuvna, for one, lamented that "although she and her whole family were of noble descent," her lack of written proof had left her without an official status. She and others like her-all illiterate, and several claiming that poverty was all that kept them from being able to prove their nobility-petitioned the Vil'na Town Duma (gorodskaia duma) in hopes of gaining entry into the local meshchanin society. They were joined by women who had somehow slipped through the cracks of imperial society: an orphan born after the last census, and thus never registered on a tax roll; a freed serf; and several women who announced themselves to have been long-time residents of the town, but "never registered anywhere on the tax rolls." ${ }^{1}$ After varying amounts of bureaucratic wrangling, all these women were eventually added to the rolls of the Vil'na meshchanin society, a mark of their new legal identity, and with that their acceptance into a particular soslovie society.

2 This revision of the census, and the petitions it provoked, bring up many issues of Imperial Russian society and governance, from control of population in the empire, to bureaucratic authority and its manifestation, to the role of writing and the act of petition. But these petitions, in particular, also highlight the fact that the Russian Empire's women had soslovie identities, and, furthermore, that they negotiated those identities. This may be an obvious statement, but it is one rarely addressed directly by 
historians. While women may appear here and there in discussions of sosloviia, they are generally absent from systematic analysis of the concept. ${ }^{2}$ And yet, women's engagement with their own soslovie identities becomes immediately apparent in an investigation of how individual Russians sought to change those identities. Although only single women - primarily those who were widowed or never married - could petition on their own behalf to leave an old soslovie behind and enter a new one, while men of any marital status were allowed such decisions, in some contexts women outnumbered their male counterparts among petitioners. This is true despite the fact that most legislation on the subject either ignored women or treated them as mere appendages to their male relatives. Therefore, their decisions to take advantage of opportunities for legal change in status, and the patterns that their choices took, show the persistent importance of sosloviia to women in particular, and, furthermore, how the meaning of membership in a soslovie was changing.

This approach to the history of sosloviia, and particularly of women's relationship with those categories, is based on a focus on the ways that individuals negotiated their sosloviia membership. That word - membership - is an important one, because individual Russians were not simply members of sosloviia on a national scale, as nobles, peasants, or townspeople, but instead were usually members of specific sosloviia organizations associated with specific geographic spaces. Peasants belonged to societies that represented particular villages and townspeople to those of particular towns. These place and estate markers were just as much a part of nominally "free" individuals' legal description of themselves as ownership was to a serf, a fact most visible in legal documents, where petitioners self-identified not simply by name, but with specific information about their geographic and estate origins. Furthermore, this membership could be and often was changed via specific legal methods. Examining those changes those moments when individuals actively affirmed their soslovie - allows us to see not just that women had a different relationship to soslovie than men, but that the way in which women related to soslovie demonstrates the changing role of sosloviia in Russian society. Their active participation in the system shows both the persistence of sosloviebased hierarchies in Russian society, and also the evolving nature of communal responsibility during the nineteenth century.

The laws that governed membership in and movement between sosloviia treated women differently from men both explicitly and implicitly. Most explicitly, marriage laws meant that women found their soslovie identities shifting not necessarily because they specifically desired such changes, but as a consequence of other life choices. Marriage never changed a man's soslovie status, but it could change a woman's. In essence, as the first Digest of the Laws put it in one of its first points, "a man of higher status shares the rights of that status with his wife, but a wife does not share her status either with her husband or her children; she herself does not lose [higher status] either with a first marriage, if it belonged to her before marriage, or with a subsequent marriage, when it was granted to her by a first marriage." ${ }^{3}$ In summarizing a whole series of individual laws, this statement above all reified the idea that sosloviia were ranked in a hierarchy. Nobility, of course, was the highest rank and the one once gained, hard to lose. But even meshchane - the lowest ranking of townsmen - ranked higher than peasants, and could share their status with wives of equal of lower status, while the fact that free (i.e., nonserf) women did not pass on their freedom to their enserfed new husbands reaffirmed serfs as the lowest, most unprivileged part of Russian society. ${ }^{4}$ 
The laws that governed the actual bureaucratic process of moving between different sosloviia, on the other hand, treat men and women differently primarily through implication alone. Few of these laws address women directly, instead focusing on general principles (applied in particular cases) that came to govern mobility by the end of the eighteenth century. These principles involved conceptions and rankings of duty: of the duties that individuals owed both to the central imperial state, and to the specific communities to which they belonged. Peter the Great famously made movement into the nobility possible through active service to the state, by allowing those who worked their way up the hierarchy of the Table of Ranks to gain first personal, then hereditary nobility. This kind of service, in other words, had particular value to the imperial state. ${ }^{5}$ But other sorts of mobility were similarly guided by concerns over duties: the duties to pay taxes, particularly the soul tax, and to provide recruits for the military.

Because many of the duties demanded by the state were levied not on individuals but on communities, their intersection with individual soslovie societies highlights the centrality of communal responsibility. Laws that governed movement between sosloviia tried to ensure not only that the state would not lose out on these duties, but also that communities would not be harmed by losing taxpayers or possible recruits. In practice that meant that individuals not yet registered on any tax roll were strongly encouraged, if not required, to register in a community, and that those who wanted to move between two different soslovie societies (either from one soslovie to another, or even within the same soslovie, but from one location to another) had to receive permission from both their society of origin and the destination society. That permission would only be granted if a given petitioner agreed to continue to pay taxes in his old community until the next census revision, proved that he was not in line to be sent into the military, and furthermore gave guarantees that he would be able to keep up tax duties in his new society. ${ }^{6}$

7 "He" is the appropriate pronoun to use, for these duties of soslovie membership on which the laws focused all accrued primarily, if not only, on men. The soul tax was by definition a tax on all male souls; recruits were exclusively men. ${ }^{7}$ Upward mobility into the nobility through service to the state likewise fell to men. ${ }^{8}$ Thus, looking only at men emphasizes the role of individual duties to the state and to individual societies in the construction and interpretation of sosloviia. When women are added to the picture, however, soslovie membership implies a very different relationship between individuals, local societies, and the state. This is evident in something as simple as the wording often used to describe how or why women were registered in, for example, town societies. In both laws and in many legal documents, women's names were written into the town records and onto household registers or tax rolls "only for the count of the people." In other words, men were legally registered in order to ensure they fulfilled their duties, but because women had no such connection to the duties relevant to their social position, communities had to register them only in the interests of keeping track of the larger population..$^{10}$ In this interpretation, women were extraneous to the communal responsibilities of the larger estate, sometimes even registered in different books, and otherwise kept outside the main work of the individual societies.

Starting in the mid-nineteenth century, the persistence of this way of seeing women on the part of central ministries began to create conflict with local societies, as they started to understand communal responsibility in a different way. On one side were decisions that saw women as unproblematic, largely extraneous, "members" of societies to which 
they owed nothing. That interpretation underlay a series of discussions between the Ministries of Finance and Internal Affairs on the question of whether women should be considered a special category when it came to legislation regarding changing sosloviia. While men had to receive permission both to leave their soslovie of origin and to enter a new soslovie, the ministries debated whether women could be classified as one of the few groups that did not need to gain formal acceptance into a new society. ${ }^{11}$ After all, the argument went, women could not trouble a new society by adding to its tax burden and then failing to fulfill their part in the communal responsibility to pay taxes. Starting at the end of the 1870s, the two ministries corresponded over several specific cases involving women seeking entrance into town soslovie societies. The Ministry of Finance concluded that because women would add no new tax burden to town societies, and because women would find refusal a hardship, the only logical course was to allow these women to register at will. ${ }^{12}$ Eventually, the Svod zakonov was amended to include the notice that all peasant and meshchanin women who wished to enter new societies as heads of households including no male souls would be allowed to do so "by only their requests, without presenting acceptance agreements," thus confirming this view of women's roles within - or, in a way, adjacent to - soslovie societies. ${ }^{13}$

Already, however, those societies were realizing that women had a more complicated place than a focus on what members owed their societies suggested. It was increasingly becoming clear that soslovie societies also owed something to their members. Societies had long "owed" their members documents that allowed work or residency at home or abroad. In 1831, a law used that reality as a basis for a decision about women of state peasant origins who wished to register in town soslovie societies. According to the law, they were allowed such registry "only if, living in towns for permanent work, it is not convenient for them to return to their previous place of residence and [therefore] it is difficult for them to receive passports." ${ }^{14}$ In other words, this law focused on one major thing that societies did for their members: they gave them the right to live in a given place, either through registry in that place, or via a passport that allowed them freedom to move to a new place. The 1831 law was in part meant to ensure that women had access to this right, one that maintained its importance in individual lives throughout the imperial period.

With changes brought about by the Great Reforms, the balance between the duties of individuals to estate societies and the duties of societies to their members began to shift ever more toward the latter. The shift began with the gradual elimination of the soul tax, first in towns, later throughout the Empire, and was continued by the Army Reform that instituted universal military service. ${ }^{15}$ These reforms meant in part that the communal responsibility of societies to fulfill these duties to the state devolved onto individual members of those societies, causing a major shift in the relationship between those societies and their members. Now, the duties that the societies owed their members starting with giving them residency permits, but increasingly including other sorts of care for their welfare - became the dominant part of the relationship. In essence, belonging to a specific soslovie society gave individuals real benefits, whether it was residency rights, an organization to speak on one's behalf, or even medical care and poor relief. ${ }^{16}$

11 At exactly the same time that central ministries were reaffirming the idea that women were extraneous to local soslovie societies, those societies themselves began to protest on the grounds that women actually did have a real place - and a possibly costly one - as 
members. In one case, local authorities in Arkhangel'sk protested a decision by their local provincial treasury (kazënnaia palata) in the case of three peasant women who wanted to enter the local meshchanstvo. From the Treasury's point of view, women could not cause trouble for a society because they had no impact on tax and recruit duties particularly in this post-Reform period. Therefore it saw no basis for refusing them official entry. But the Arkhangel'sk meshchanin society disagreed. They did not want to accept the women precisely because they were likely to cause them problems, although problems not with arrears, but with demands for services: "Registry goes along with expenses on the part of the society for the welfare and medical care in hospitals of registered individuals who are ailing, to the point that the Arkhangel'sk meshchanin society already owes just the local hospital more than 3,000 rubles for the care of insolvent meshchane." ${ }^{17}$

Although in this case the Arkhangel'sk society left unsaid the idea that these unattached women might be more likely to fall on the mercy of the society at some point in the future, other writers were not so reticent. Evgenii Blumenbakh, a bureaucrat from Riga, wrote several pieces on soslovie societies at the turn of the century, and concluded that town societies had come to be occupied most of all with "the care of the poor and the healing of the sick." As he put it, only members of a society "may take advantage of the protection of the town society in case of poverty, infirmity, or illness, because by paying local taxes they gain the right to help from the society." There was, however, an exception: women. Although according to current statutes, women paid no community taxes, "more than half of the money for welfare and medical care is spent on women." 18 Other reports confirmed the idea that women could and did take up a disproportionate share of the resources of local societies. ${ }^{19}$ Women thus became a particular sign of this alternative interpretation of communal responsibility: not communal responsibility to fulfill duties, but communal responsibility to ensure the welfare of a society's members.

The place of women in the legislation and administration of sosloviia suggests that sosloviia were viewed as part of a real hierarchy from low to high, and also that the nature of soslovie membership was changing during the second half of the nineteenth century. Where soslovie membership once focused on duties to the state, it came to represent the possibility of stability and welfare. The patterns of how individual women negotiated their soslovie membership over the nineteenth century - or, at least, those patterns still visible in the archival base - help to reaffirm these notions, suggesting that the hierarchy visible in legal descriptions of the soslovie system were further complicated by both geography and the very promise of stability granted by entry into certain statuses.

Laws regulating soslovie membership, like those regarding marriage, clearly saw town societies of any kind as "higher" than rural societies, and free rural societies as higher than serf ones. The archives confirm that those "higher" statuses were indeed more desirable. The archives of provincial town administrations in charge of both accepting and releasing members contain more cases of peasants of various kinds seeking to enter town sosloviia than members of town sosloviia seeking to enter peasant societies: between 1801 and 1917 the former outnumber the latter by just over 3 to $1 .{ }^{20}$ The overwhelming majority of rural migrants to provincial towns were seeking to join local meshchanin societies as opposed to the merchant or craft societies (95 percent of all such migrants, compared to 4 percent and 0.4 percent, respectively). These last two social estates required specific qualifications for entry, like the accumulation of capital or attestations of a craft, and thus were by their very nature harder to enter. Furthermore, the 
merchants were a definitely privileged status due to their exclusion from the soul tax. Meshchane, on the other hand, owed the same soul tax and recruit duties as peasants. Their sheer location, in towns, away from the village, gave even them the image of relative privilege.

These overall numbers, however, belie significant variations that suggest that this understanding of a soslovie hierarchy was far from static. First, the picture changes radically after Emancipation. Before Emancipation, movement from village to town outnumbered the reverse by more than 11 to 1 ; after, that ratio shrank to a mere 1.4 to 1 . This change likely suggests not so much that towns became less desirable after Emancipation - evidence about migrant workers more generally would strongly argue against such an interpretation - but rather that the village, now freed from the taint of serfdom, became more desirable. A meshchanin society might have seemed a major improvement over the lot of a serf in the pre-Emancipation era, but once the excesses of serfdom were removed from the system, that stark difference seemed less severe. The result was essentially a flattening of the estate hierarchy, as nearly as many people wanted to leave town societies for rural ones during this period. ${ }^{21}$

Gender was a second source of variation in the pattern of movement between town and village, and a variation that speaks to the resilience of soslovie hierarchies for some of the Russian population. Both men and women found the village more attractive after Emancipation, but women still valued membership in town sosloviia more than men. Over the entire period, women moving from rural to town societies outnumbered their opposites by nearly 8 to 1 , compared to just over 2 to 1 for men. They were particularly unlikely to move from towns to villages in the pre-Emancipation period (the ratio then was 61 to 1 against such moves), but even after Emancipation, when men moved between town and village almost equally, women were still more than three times as likely to move to towns than from them. ${ }^{22}$ There are outside factors that might account for this disparity. One was the change to the law allowing women to enter meshchanin societies without the need for gaining formal entrance. But other possible factors based in the village are more contradictory. On the one hand, the post-Emancipation village, at least in areas that produced large numbers of migrant workers, became, in a way, a women's fiefdom. ${ }^{23}$ But at the same time, peasant women without husbands received, in a way, even less economic freedom from the Emancipation than did their male counterparts, as village authority over land allotments was likely to discriminate against them - a reason, it is suggested, that many chose to leave. ${ }^{24}$

The experience of women in the capitals adds another way to think about the hierarchy of sosloviia: that not only were urban sosloviia preferred to rural ones (particularly, and consistently, by women), but the most urban (the capitals) were most preferred. ${ }^{25}$ Women were more likely to join the meshchanin societies of the capitals than they were to join the analogous societies in provincial towns. In the provincial records, women petitioners constituted a substantial minority of cases: 27 percent of all such petitioners over the whole period, representing a shift from 25 percent of cases before the Emancipation to 30 percent after. In the capitals, however, a much higher percentage of those entering meshchanin societies were women. In four years at the beginning of the nineteenth century (1814-1817), 55 percent of all petitioners seeking entrance into the Moscow meshchanstvo were women. Nor was this an anomaly. According to the neighborhood books of Moscow's Sretenskaia sloboda, between 1836 and 1896, fiftythree percent of its 741 new members were women. ${ }^{26}$ In this case, the proportion of 
women entrants declined after Emancipation, from a high of 92 percent before, to 47 percent after, but even that lower number is significantly higher than provincial patterns. Even in the early twentieth century, women continued to enter the Moscow society in large numbers, making up 46 percent of petitioners between 1903 and 1917. ${ }^{27}$ In every case women were more likely to join the capital's meshchanin society than they were to join provincial ones.

The image of a relatively neat hierarchy of sosloviia based not just on official status, but also on place, becomes more complicated when one considers the social origins of petitioners. First, although they made up the majority of cases, rural petitioners were only part of the story. In provincial towns, serfs and peasants taken together consistently made up the largest segment of those entering meshchanin societies: 59 percent of all petitioners. But petitioners seeking entry into meshchanin societies came not only from various peasant categories, but also from military (11 percent) and church statuses (15 percent), and even from other town statuses (4 percent of petitioners were merchants). However, again there were significant differences between the genders, and differences between the pre- and post-Emancipation periods. Women petitioners, particularly before the Emancipation, were overwhelmingly of peasant origin (90 percent before, 78 percent after); men, on the other hand, were less rural, and saw a different shift in their composition ( 42 percent peasant before the Emancipation, 66 percent after). This shift in the pattern of men's petitioning indicates less the rise of peasant petitioners, but instead the fall in another group: members of church estates. Before Emancipation, those released from church authorities accounted for 26 percent of all male petitioners; after, the percentage shrank to three percent. This huge drop may well be yet another indication of the flattening of the soslovie hierarchy for men during the late nineteenth century. Movement between the two lower statuses of meshchanin and peasant increased compared to other kinds of movement, while church men now bypassed the meshchanstvo as they entered lay society. ${ }^{28}$ For women, however, now the meshchanstvo seemed like a viable option for more than just peasants. ${ }^{29}$

If different sosloviia had indeed come to be valued differently by men and women toward the end of the century, the key may be found in another aspect of the social origins of petitioners: family and the social support it did or did not provide. First, the marital and family status of women petitioners into the merchantry - the higher town estate emphasizes how out of reach that status really was for women, particularly after Emancipation. Before Emancipation, only three percent of rural women petitioning for entry into provincial towns sought registry as merchants, compared with six percent of men; after the Emancipation no women $\operatorname{did}^{30}$ But even these modest numbers may be misleadingly high. The 1824 law that restated certain rules for guild membership addressed this point in some detail; for the purposes of capital accumulation, a family could consist of a father with children and grandchildren not counted separately; a widow with sons, unmarried daughters, and grandchildren, "when they all live in one home not separately;" or of brothers and unmarried sisters, again "when they live in one home." ${ }^{31}$ As a result, in at least some cases, women petitioned to enter the merchant soslovie less on their own behalf than on behalf of their adult sons, in order to keep the family capital together. Marem'iana Rodionova, a freed household serf widow, was the petitioner of note in an effort to join the Moscow merchant society, but her sons drew up all the paperwork and signed all the required documents. ${ }^{32}$ Although other cases show less clear effort on the part of sons, a random sampling of women petitioners shows that 
all entered with at least one adult son, and thus were part of a larger family structure and economy they were trying to preserve. ${ }^{33}$

Because of the difficulties in entering other town societies, and the undesirability of village societies, the meshchanstvo was continually, and perhaps increasingly, the focus of women's efforts to change their legal status. Why did so many women gravitate toward a legal position that bound them to a status increasingly seen as backward - or, as one late nineteenth century commentator put it, to the "forgotten soslovie"? $?^{34}$ In some cases, women who entered meshchanin societies may have had little choice in the matter. This was certainly true of most of the women seeking to register in Vil'na in 1835, and could be said to be true of many of the freed serfs from the start of the century, and members of other categories later on in the century. They, in principle, at least, had to choose a status, and the meshchanstvo was more available than most. But this may understate the degree of agency in women's decisions to enter the new estate. Formally registering in a soslovie society was not free, either in effort (gaining all the documents required, appearing in person for hearings) or in cash (for paper, for scribes, for registration). These could be so burdensome that one freed serf, Avdot'ia Evseeva Kolotukhina, petitioned the Minister of Internal Affairs himself to intervene in her request to join the St. Petersburg meshchanin society. She was, she wrote, too poor to pay the costs associated with registry, and asked that they be waived. ${ }^{35}$ Even after the central ministries decided that women could be added to meshchanin societies with little administrative fuss, some of those societies demanded special payments from women applicants, thus erecting another barrier to formal registration. ${ }^{36}$ Given the masses of peasant migrants in cities, particularly the capitals, the temptation to remain unregistered and hidden had to have been great. Therefore, those who chose to formalize their legal position as members of societies did likely, or at least in many cases, seek something out of their new status.

21 Again, family and marital status likely strongly influenced women's decisions about joining meshchanin societies. Perhaps particularly in large cities like the capitals, the promise of at least some degree of social services available to all who registered had to appeal to the women who petitioned on their own behalf: unmarried women, often with children, and sometimes of advanced years. ${ }^{37}$ The neighborhood books of Moscow's Sretenskaia sloboda show that men almost always entered the meshchanin society with wives and families: 85 percent did so, while only 15 percent entered as single men. But women had, on the whole, very different family situations. They were by definition spouseless - 36 percent of women entering the Moscow meshchanin sloboda were widows, while 64 percent had never been married. Despite this, 28 percent of women petitioners brought with them family members, usually children, often illegitimate. Unlike the cases of women entering the merchant estate with adult sons, these children were all under age, requiring more support from their mothers than supplying it. And that requirement likely influenced women's decisions formally to register.

Both single women and those supporting families as single mothers could find real reason to register in towns. For single women, town societies could provide security when family could or would not. While certainly many single women were registered as members of meshchanin societies for purely bureaucratic reasons (wards of foundling homes were often registered en masse when they "graduated" from those institutions, for example) some seem to have been searching for social support in places in which they already lived. ${ }^{38}$ Some were simply without family, and registry gave them an official 
place, as was the case for twenty-one-year-old Elena Andreeva Solov'ëva, who requested formal entry into the St. Petersburg meshchanin society in 1898 . Solov'ëva was by birth a peasant from Penza province and furthermore "a total orphan, having no relatives." But her residency in St. Petersburg - and perhaps her literacy? - made her want to register in the city. ${ }^{39}$ Others sought more tangible support in the charitable institutions run by meshchanin and craft societies. Also in 1898, several older women made special contributions to the St. Petersburg meshchanin almshouse as part of their requests for formal entry into the society. One, Anna Varlamova Akulova, aged seventy-six, made the reason explicit in her formal petition, requesting that "when I am registered in the Society place me in the St. Petersburg meshchanin almshouse."40

Single mothers might also find town societies to be sources of significant social support unavailable in their home societies. In several cases, the women who entered meshchanin societies with children were of noticeably different soslovie origins than women more generally. In 1859, seventeen women finalized their admission to the St. Petersburg meshchanin society as heads of families that included male souls. ${ }^{41}$ For the most part, these were single mothers, and often (in eleven cases) of illegitimate children. More unusually, only three of these petitioners came from serf backgrounds, while most of the rest were state peasants, representing a far greater proportion than in the general pattern. Similarly, in 1892 seven women entered the St. Petersburg meshchanstvo with children; although at that time only 39 percent of the total women entering the society were of peasant origins, six of the seven women with children were. This unusual prevalence of peasants whose lives were structured by their villages rather than their owners among these samples suggests that such single mothers, and perhaps particularly those of illegitimate children, were unwanted by their home societies, and had been pushed out, rather than chosen their new lives. Or, perhaps, that they had chosen their new lives in hopes of finding there better support for their families than had been available in their villages. ${ }^{42}$

While a sheer urge for survival, and for the social network that could provide it, seems part of the reason for women's particular draw to meshchanin societies by the end of the century, the idea that entry into a meshchanin society might be a first step toward greater social advancement may also have contributed to their decisions. Certainly some single women were reduced to life in the almshouse after their entry, but just as many, according to the records of the societies themselves, had lives that were successful by any measure. Many married. Some continued their upward movement within town society by entering the merchant estate themselves. Others studied, and left the meshchanin society with one of the new professional statuses (teachers, artists, midwives). ${ }^{43}$ The experiences of women who entered town societies as single mothers show yet more successes. Take the women who joined the St. Petersburg society in 1892. All of their children seemed to thrive in the capital. Many married and had children of their own. The son of Mariia Ivanova Botina, one of the former peasants, became a first guild merchant in 1912. Mariia Ivanova Kryzheva's three children, all illegitimate, were all eventually excluded from the meshchanin society because they gained new positions: two daughters qualified as teachers, and a son graduated from the Technological Institute and earned the status of personal honored citizen in 1904. And Varvara Nikolaeva Bobrova was able to extend support to others after her establishment in the town; in 1908, she adopted the illegitimate daughter of a peasant. ${ }^{44}$ Even if these women started out in marginal positions, whether in the eyes of the legal authorities, or their home societies, or even their new ones, they soon became full-fledged members of their 
new society whose families thrived with the opportunities available to them and their children.

This focus on women's experiences of the mutability of sosloviia identities, as they changed their legal status either by necessity or by choice, helps explain the persistence of sosloviia in the face of the modernizing thrust of the late imperial state. ${ }^{45}$ Some observers interpreted late imperial society as increasingly non- or supra-soslovie in its taxation and recruiting policies, in its administration and in its economic structures, and men's experiences could arguably be interpreted as supporting the idea of waning importance. But women's experiences suggest something very different. For one, the central state's interpretation of women as somewhat extraneous members of soslovie societies, emphasized the continued importance of soslovie identities as pure markers of social control: there was no real reason for the imperial state to demand women's registry, after all, were it not for its desire to keep track of its population. But even more, women's experiences of binding themselves to a given society, particularly a town society at a time when the larger population of migrants in towns was remarkably fluid and impermanent, ${ }^{46}$ speaks to a different kind of krugovaia poruka, a collective responsibility that revolved as much around social support as social control. This approach shows that sosloviia did not just control Russian society, and did not just privilege the few at the expense of the many, but also persisted as real institutions within the larger society, institutions that gave real benefits to their members, and a real chance for success even for the formerly marginal.

\section{NOTES}

1. LVIA (Lietuvos valstybės istorijos archive - Lithuanian State Historical Archive) f. 937 (Vil'na Town Duma), op. 1, d. 1909, 1. 1, 6, 8, 10, 14, 18, 22, 30, 48.

2. Women are either completely absent or barely mentioned in several of the major recent works on soslovie, including Gregory L. Freeze, "The Soslovie (Estate) Paradigm and Russian Social History," American Historical Review, 91, 1 (Feb. 1986): 11-36, and Michael Confino, "The Soslovie (Estate) Paradigm: Reflections on Some Open Questions," Cahiers du Monde russe 49, 4 (Oct.-Dec. 2008): 681-699. Women appear in Elise Kimerling Wirtschafter, Structures of Society: Imperial Russia's "People of Various Ranks" (DeKalb: Northern Illinois University Press, 1994) and Social Identity in Imperial Russia (DeKalb: Northern Illinois University Press, 1997), but other than in a brief introductory section in the latter volume, only sporadically. Perhaps because it focuses so narrowly on legal sources, Natal'ia Anatol'evna Ivanova and Valentina Pavlovna Zheltova, Soslovnoe obshchestvo Rossiiskoi imperii (M.: Novyi Khronograf, 2009) also barely mentions women.

3. Svod zakonov Rossiiskoi Imperii: Zakony o sostoianiiakh (Digest of the Laws), (SPb.: II Otdeleniia Sobstvennoi ego Imperatorskogo Velichestva Kantseliarii, 1833) [hereafter Zakony o sostoianiiakh 1833], 5. This provision remained largely unchanged (with only the addition that women who had been stripped of the rights of status by legal process were 
not eligible to regain them through marriage) in the 1899 edition of the code. See Zakony o sostoianiiakh (SPb.: N.K. Martinov, 1901), 3.

4. See, variously, Polnoe sobranie zakonov Rossiiskoi Imperii: Pervoe sobranie (SPb., 1830) [hereafter PSZ (1)], vol.22, no. 16187, st.3, 7; vol. 29, no. 22726; vol.32, no. 25740 (on nobles); vol. 22, no.16188, st. 82 (on meshchane); vol. 30, no. 23027 (on church estates); vol. 33, no. 25947, p. 7 (on "widows and unmarried women of free status").

5. Lindsey Hughes notes that the Table of Ranks was really intended to benefit the state above all. See her Russia in the Age of Peter the Great (New Haven: Yale University Press, 1998), 184.

6. One of the first statements of such a principle came in a law governing the registration of peasants as merchants. See PSZ (1), vol. 15, no. 11426 (Jan. 31, 1762). Because the Russian legal system worked by legislating every possible permutation of a practice, rather than on general principles, more laws soon followed governing almost every pairing of sosloviia of origin and of destination. They include PSZ (1), vol. 19, no. 13453 (April 29, 1770); vol. 20, no. 14343 (July 1, 1775) and no. 14632 (July 25, 1777); vol. 22, no. 16235 (July 30, 1785); vol. 24, no. 17695 (Dec. 29, 1796) and no. 18213 (Oct. 21, 1797); vol. 30, no. 23092 (June 14, 1808); vol. 31, no. 24517 (Feb. 9, 1811); and vol. 37, no. 28855 (Dec. 31, 1821). Laws continued to develop, giving, for example, tax waivers to petitioners to ease their paths, but the goal was always to get people on tax rolls as efficiently as possible.

7. Merchant women who traded on their own behalf were subject to the same taxes as their male counterparts. PSZ (1), vol. 22, no. 16188 (21 April 1785). But merchants were also among the least likely to seek to change status via this sort of petition, although in general their status was extremely liable to change. A business failure could cause them to fall into the meshchanstvo via statutory fiat, or education could set merchant sons on the path to state service. Alfred J. Rieber, Merchants and Entrepreneurs in Imperial Russia (Chapel Hill, 1982), 31-39.

8. Wirtschafter, Social Identity, 10.

9. The phrase appears in ukases sent from local kazënnye palaty finalizing the registration of women in new societies. See GARO (Gosudartsvennyi arkhiv riazanskoi oblasti), f. 49 (Riazan' Town Duma), op. 1, d. 151, passim, and d. 278, 1. 1-2; LVIA, f. 937, op. 2, d. 103. It seems to have been taken from laws pertaining to certain tax-exempt men who were to be nonetheless registered in towns or villages. See Zakony o sostoianiiakh 1833, no. 402, which applies that phrase to retired soldiers. More generally, this fact was cited as one of the many inadequacies of Russian census practices - because women were included "only for the count," there was little reason to take care in drawing up revision lists. See Iu.E. Ianson, "Ustroistvo pravil'noi perepisi naseleniia v Rossii," in V.P. Bezobrazov ed., Sbornik gosudarstvennykh znanii, vol. 1, (SPb.: D.E. Kozhanchikov, 1874), 163-164.

10. Although women were first counted during the third (1762) revision, it was only with the 1781 census revision that women were to be listed in separate places on official forms, and the count of both was to be, in principle, at least, exact. See PSZ vol.21, no. 15296 (Dec. 10, 1781) for the Senatorial Ukase announcing changes to forms, and V.M. Kabuzan, Narodonaselenie Rossii v XVIII-pervoi polovine XIX v. (M.: Akademiia nauk SSSR, 1963), 65.

11. The 1833 Svod zakonov listed five categories of petitioners allowed to register as townspeople without formal acceptance: members of the church estates freed from that estate, serfs freed by legal judgment against their owners, wards of Foundling Homes 
(who were grouped with illegitimate children), Jews who had converted to Christianity, and single householders from the western provinces. For the most part, the goal of these exclusions were to get more people on the tax rolls, or to give a benefit to those who had acted in a way pleasing to the state. See Zakony o sostoianiiakh 1833, 251.

12. RGIA (Rossiiskii gosudarstvennyi istoricheskii arkhiv), f. 1287 (Ministry of Internal Affairs), op. 38 (Economic Department), d. 1674, 1. 6, 11-11ob.

13. Ibid., 1. 59-60ob (1888).

14. Zakony o sostoianiiakh 1833, st. 257. Much the same language was used by individuals seeking freedoms, either from their soslovie societies or from individual owners. In 1835, for example, the serf Afin'ia Semenova petitioned her owner, Count Sheremetev, asking for her freedom because "on your estate we have no property of any kind in order to feed ourselves, and so live here in Moscow and from our labor we feed ourselves - though with great difficulty - and every year we have difficulty in getting our passports." Her request was not, however, granted. RGIA, f. 1088 (Sheremetevy), op. 3, d. 956, 1. 5-6ob. Much later, Mariia Mikhailovna Ershova, the widow of the son of a personal honored citizen, found herself in a similar position, and in 1908 petitioned the Moscow Provincial Treasury for registry in the meshchanin society of Kolomna, "from which I may request for myself residency papers." See TsIAM (Tsentral'nyi istoricheskii arkhiv Moskvy), f. 54 (Moscow Kazënnaia palata), op. 57, d. 29, 1.1 (petition, received 22 March 1908).

15. On tax reform as part of a shift away from collective responsibility in tax collecting, see Yanni Kotsonis, “'No Place to Go': Taxation and State Transformation in Late Imperial and Early Soviet Russia," Journal of Modern History 76, 3 (Sept. 2004): 538.

16. Lynne Sargeant notes that in 1893, several Moscow-based "free artists," a status conferred on professional musicians who had been freed from their sosloviia of origin, complained that being without soslovie representations put them in a difficult situation, without "defined civil rights." See "A New Class of People: The Conservatoire and Musical Professionalization in Russia, 1861-1917," Music \& Letters 85, 1 (2004): 45.

17. RGIA, f. 1287 , op. 38 , d. $1674,1.28 \mathrm{ob}$. In the end, the ministry did not find this argument convincing, and agreed that because the law allowed meshchanin women to transfer from one town to another without formal acceptance, it would "hardly be right" to demand such documents for peasant women (1.29ob).

18. Evgenii Blumenbakh, Grazhdanskoe sostoianie (soslovie) $v$ Rossii, a $v$ chastnosti $v$ pribaltiiskikh guberniiakh ego prava i obiazannosti (Riga: Ernst Plates, 1899), 30 and Evgenii G. Blumenbakh, Dokladnaia zapiska $i$ proekt reorganizatsii soslovnykh obshchestv $i$ uchrezhdenii v Rossiiskom gosudarstve (Riga: V.F. Gekker, 1917), 3, 5; RGIA, f. 1287, op. 38, d. 1674, l. 54-5 (1885).

19. V.P. Okhochinskii, Bogadel'ni, priiuty dlia padshikh zhenshchin $i$ deshëvye kvartiry (SPb.: Vtoroe otdelenie Sobstvennoi E.I.V.Kantseliarii, 1877), 82; Materialy dlia istorii Pokrovskoi bogadel'ni i Aleksandro-Mariinskogo remeslennogo uchilishcha Moskovskogo meshchanskogo obshchestva, vol.1 (M.: I.M. Mashistov, 1892), 6-17. On soslovie responsibilities more generally, see also Iu.M. Goncharov and V.S. Chutchev, Meshchanskoe soslovie zapadnoi Sibiri vtoroi poloviny XIX-nachala XX v. (Barnaul: Az Buka, 2004), 89-98.

20. Discussion of "provincial towns" or "the provinces" is based on a database of 2,113 cases listed in provincial archival registers from Tver', Riazan', Iaroslavl', and Saratov, dating from 1801 to 1917. The relevant archival funds are: GATO (Gosudarstvennyi arkhiv tverskoi oblasti), f. 21 (Tverskaia gorodskaia duma); GARO, f. 4 
(Riazanskoe gubernskoe pravlenie), f. 49 (Riazanskaia gorodskaia duma); GAIaO (Gosudarstvennyi arkhiv iaroslavskoi oblasti, f. 79 (Iaroslavskoe gubernskoe pravlenie), f. 100 (Iaroslavskaia Kazënnaia palata), f. 501 (Iaroslavskaia gorodskaia duma); and GASO (Gosudarstvennyi arkhiv saratovskoi oblasti), f. 2 (Saratovskoe gubernskoe pravlenie), f. 3 (Saratovskaia gorodskaia duma), f. 15 (Saratovskii gorodskoi magistrat), f. 28 (Saratovskaia Kazënnaia palata), f. 94 (Saratovskaia meshchanskaia uprava).

21. Another way of seeing this flattening is in the reduced distinction between town sosloviia in the late imperial period, described in Goncharov and Chutchev, Meshchanskoe soslovie, 34. Although the fact that the rural population far outnumbered the urban one might call into question the idea of ranking urban and rural statuses, it should not affect either this chronological variation, or the variance based on gender noted below.

22. Furthermore, some of the women petitioning for such changes may have been doing so not fully on their own behalf. In 1900 the St. Petersburg meshchanin widow Vassa Gladkova petitioned for release from the society for her family. But it was her oldest son, not she, who had received acceptance to join a peasant society in Iaroslavl' province. TsGIASPb (Tsentral'nyi gosudarstvennyi istoricheskii arkhiv Sankt-Peterburga), f. 222 (Sankt-peterburgskaia meshchanskaia uprava), op. 1, d. 534, 1. 1-4.

23. Barbara Engel, “The Women's Side: Male Outmigration and the Family Economy in Kostroma Province," in Ben Eklof and Stephen Frank, eds., The World of the Russian Peasant: Post-Emancipation Culture and Society, (Boston: Unwin Hyman, 1990), 65-80.

24. Robert Eugene Johnson, "Family Relations and the Urban-Rural Nexus: Patterns in the Hinterland of Moscow, 1880-1900," in David L. Ransel, ed., The Family in Imperial Russia: New Lines of Historical Research, (Urbana: University of Illinois Press, 1978), 272.

25. Records still extant in Moscow and St. Petersburg are more limited in chronological scope, but at times deeper in content. The discussion below draws on the same kind of register sampling used for the provinces (mostly from TsIAM, f. 32 [Moscow Magistracy], op. 9, which lists records of 1,873 petitioners to enter the Moscow meshchanin society), as well as records that list either all households in a given sloboda (neighborhood), with notation on those who left or who entered the society, or that list all new entrants into the city's meshchanin or tsekhovoi society in a given year, from TsIAM, f. 5 (Moskovskaia meshchanskaia uprava) and TsGIASPb, f. 222 (Sankt-peterburgskaia meshchanskaia uprava).

26. Sretenskaia was a relatively "average" sloboda; the records in the extant neighborhood books run from the eighth census revision (1835) until the end of the Imperial period, but their records degrade in quality toward the end of the period.

27. TsIAM, f. 5, op. 1 , d. 260. Because of some peculiarities in recording data, the data from 1911-1913 is spotty and difficult to interpret, and is thus excluded. Because of the way the St. Petersburg meshchanin board kept records (and because of difficulties gaining access to those records at the St. Petersburg archive), I only have material to compare men and women's rates from one year: 1892. But in that year, women made up 55 percent of entrants into the St. Petersburg meshchanstvo, a rate certainly more comparable to those in Moscow than to those in the provinces. TsGIASPb, f. 222, op. 1, d. 421-422.

28. Reform-era changes in the status of priests' sons particularly increased their access to education; these changes would let them leave the church and enter into state service or the new professions, bypassing the meshchanstvo. See Laurie Manchester, Holy Fathers, 
Secular Sons: Clergy, Intelligentsia, and the Modern Self in Revolutionary Russia (DeKalb: Northern Illinois University Press, 2008), 156-159.

29. Records from Moscow also support this interpretation. Between 1814 and 1817, ninety-four percent of all women petitioning to enter the meshchanin society were freed serfs. By the middle of the century, former serfs still predominated, but state peasants, in particular, became more common (around five percent of cases). After the Emancipation, the proportion of former peasants among women entrants continued to shrink, down to 66 percent of the total. In Moscow, men's experiences diverge somewhat from the provincial cases, as the proportion of male peasants went down after Emancipation, from 69 percent to 41 percent. This suggests that although the social hierarchy might have flattened, the hierarchy of place had not.

30. That said, this represented 20 percent of all petitioners to enter the merchant estate before the Emancipation; in comparison, women made up only nine percent of all those who entered the Moscow merchant estates between 1810 and 1888; or, 11 percent before the Emancipation (data compiled from registers of TsIAM, f. 2, op. 1 and f. 3, op. 1).

31. See Rieber, Merchants and Entrepreneurs, 27 and PSZ vol. 39, no. 30, 115 (Nov. 14, 1824).

32. TsIAM, f. 2, op. 1, d. 1622 (1824). See also TsIAM, f. 2, op. 1, d. 582, 1. 1a, 9 (1818) and d. 3391, 1. 1, 4 (1841) for more examples of sons handling documents for their mothers.

33. TsIAM, f. 2, op. 1, d. 87, 1.1-1ob (1814); d. 123, 1.1 (1814); d. 200, 1.1 (1815); d. 440, 1.1 (1817); d. 2353, 1.1-1ob (1828); d.3178, 1.1 (1838). In some cases, individual sons asked separately to break off from the family, as the case of Avdot'ia Matveeva, whose oldest son Dmitrii asked to separate from the household of his mother and two brothers. TsIAM, f. 2, op. 1, d. 114, 1. 1, 3 (1814). And Stepanida Ivanova, who initially petitioned as the head of a household, was in the end registered in the meshchanin society, while her son (who ran a restaurant) and his family entered the merchant estate. TsIAM, f. 2, op. 1, d. 2383, 1. 1, 10ob (1829).

34. Ia. Abramov, “Zabytoe soslovie," Nabliudatel' 4, no. 1 (Jan. 1885): 269-303.Vera Dunham further notes that by the end of the nineteenth century the term meshchanstvo had acquired distinctly negative connotations. Vera S. Dunham, In Stalin's Time: Middleclass Values in Soviet Fiction, Enlarged and expanded edition (Durham: Duke University Press, 1990), 19.

35. RGIA, f. 1287, op. 37, d. 330, 1.1-1ob (1846). See also the case of Nastas'ia Pavlova, another freed serf asking for a fee waiver. GARO, f. 49, op. 1, d. 553, 1. 10 (1860).

36. Proekt ustava Doma prizreniia prestarelykh $i$ uvechnykh grazhdan $i$ Doma prizreniia maloletnykh bednykh S.-Peterburgskogo meshchanskogo obshchestva (SPb.: E. Treiman, 1875), 3, ftnt; LVIA, f. 1394, op. 1, d. 584, 1.5 (1869); d. 585, passim (1893).

37. Here the hierarchy of place becomes apparent, as in some regions, at least, district level towns had very few social amenities, and provincial towns some more. See A.P.Kaplunovskii, "Meshchanskaia obshchina," in Ocherki gorodskogo byta dorevoliutsionnogo Povolzh'ia (Ul'ianovsk: Srednevolzhskii nauchnii tsentr, 2000), 391-393.

38. For example, TsGIASPb, f. 222, op. 1, d.503, 1.164u-165v consists of a long set of documents supporting the acceptance of 199 girls born in 1877 from the Imperial St. Petersburg Foundling Home into the St. Petersburg meshchanin society in 1898.

39. TsGIASPb, f. 222, op. 1, d. 503, 1. 1, 2 . 
40. TsGIASPb, f. 222, op. 1 , d.503, 1.347-9. Similarly, a large number of the women entering the Moscow meshchanin society during the mid-nineteenth century ended up in local poor houses, even if not the local meshchanin one. TsIAM, f. 5, op. 1, d. 213.

41. TsGIASpb, f. 222, op. 1, d. 1108.

42. Although these were not necessarily options. When Elena Vasil'eva Rubakova petitioned the St. Petersburg meshchanin society for entrance in 1898, she had to sign a statement that she would not seek a place for her son in one of the society's charitable institutions for impoverished children. TsGIASPb, f. 222, op. 1, d. 503, 1. 257.

43. TsGIASPb, f. 222, op. 1, d. 506, passim.

44. TsGIASPb, f. 222, op. 1, d. 421, 1. 197, 46, 150.

45. As Confino points out, the notion that sosloviia were "flourishing" even in the very late imperial period was the "really novel element" in Freeze's important article. Confino, "The Soslovie (Estate) Paradigm," 685.

46. Robert Eugene Johnson, "Peasant Migration and the Russian Working Class: Moscow at the End of the Nineteenth Century, Slavic Review 35, 4 (Dec. 1976): esp. 657-660.

\section{ABSTRACTS}

Abstract

This paper draws on published laws and extensive files from central and provincial Russian archives to examine the ways in which women negotiated their own soslovie status by actively petitioning to enter new sosloviia societies, and finds that not only did women have a different relationship to soslovie than men, but also the way in which women related to soslovie demonstrates the changing role of sosloviia in Russian society. Their active participation in the system shows both the persistence of soslovie-based hierarchies in Russian society, and also the evolving nature of communal responsibility during the nineteenth century, from one based on the duties of individuals to the commune or the state, to one based more on the responsibilities of the commune to the individual.

Résumé

Cet article met en avant des lois publiées et d'importants dossiers des archives centrales et provinciales russes et examine la façon dont les femmes négociaient leur propre statut en adressant des requêtes pour être intégrées à de nouveaux ordres. L'article montre que non seulement la relation des femmes aux ordres était différente de celle des hommes, mais qu'en plus elle témoigne du rôle changeant des ordres dans la société russe. La participation active des femmes au système montre à la fois la persistance, dans la société russe, d'une hiérarchie basée sur les ordres et aussi la nature évolutive de la responsabilité communale au cours du XIX ${ }^{\mathrm{e}}$ siècle, qui est passée d'une responsabilité basée sur les devoirs de l'individu vis-à-vis de la communauté ou de l'État à une responsabilité de la communauté envers l'individu. 


\section{AUTHOR}

ALISON K. SMITH

University of Toronto, Department of Historyalison.smith@utoronto.ca 